\title{
WRITTEN SPEECH ACTS FOUND IN ADVERTISEMENTS ON INDONESIAN ONLINE NEWS WEBSITES
}

\author{
Nurhapsari Astriningsih \\ 171242001@usd.ac.id \\ Widiarto Adhi Setiawan \\ 171242010@usd.ac.id \\ Barli Bram \\ barli@usd.ac.id \\ Sanata Dharma University
}

\begin{abstract}
This study attempts to help senior high school English teachers in developing their teaching material about advertisement, which is included in the state mandated curriculum. Having analyzed 20 advertisements, we found two types of speech acts, namely representatives and directives. The representative acts used were 59\% and directive acts were $41 \%$ of the data. The advertisement strategy in Indonesia utilized representative acts, which intended to highlight the good quality of the products or services, whereas, the use of directive acts was situational since it is usually preceded by the appearance of representative acts. Since both speech acts frequently appeared in the advertisements on Indonesian online news websites, we recommend that teachers should provide exposures toward the linguistic features, which support students' ability to produce advertisement texts containing representative and directive acts.
\end{abstract}

Keywords: speech act, advertisement, online news website

\section{INTRODUCTION}

The use of gadgets facilitates people to get a quick access to information. Nowadays, many news media, which are originally paper-based, also provide news services in the form of online through their news websites. Accessing online news is easier, faster and facilitates people to get more updated information since they do not have to wait until the next day after the newspapers are published. A study in Australia finds that internet has become the most relied-on news and information 
source (Nguyen \& Western, 2006), whereas several studies in the US and Europe show that the shift in access, to news from printed media to the internet, has taken place from the mid-90s (Chyi \& Chada, 2011).

During accessing news websites, we often encounter intrusive online advertisements that suddenly appear on the pages. A study on the influence of language used in online advertisements has proposed that word choices have a very significant impact on newsreaders to pay more attention to them when they appear on the web pages. The research finds that word choices can play a major role on user attention to advertising (Ferreira, et al., 2011). With the right word choices, it is expected that at least readers will take a close look to the advertisements and become interested in the products or services offered. Moreover, Williamson (1978) proposes that language can be a precise reference to advertise since it is the most accessible among the other forms used in ads, like images, music, or motion pictures.

Written language used in advertising is related with the function of advertisement to persuade people to consume the products or use the services (Williamson, 1978). Advertising implements its functions using language to build images, consumers and relations. The written language is set to describe the goods or services offered and deliver messages from the advertisement itself. When using written language in an advertisement, the advertiser needs to consider the effectiveness of the sentences, phrases or word choices in order to deliver the message to its readers. It is when communicating the message that the advertiser actually produces speech acts.

Speech act concern with what people intend to do through the language. It is not only about the meaning of the language but it also performs some acts behind the language. Austin suggests there are many diferent things people can do with words. The languages we produce are not only statements or questions about some piece of information, yet they contain actions (Austin, 1962). Austin's view shows that words are not only something we use to say things but also to do things. Moreover, Searle (1969) argues that by producing expressions, people also produce speech acts, namely the propositional meaning and a function-indicating device, which marks the illocutionary force, or we can simply say illocutionary acts.

Considering advertisements are a form of written speech acts, this study aims to find 1) the type of speech acts used and 2) the most frequent speech act presented in the written advertisements in Indonesian online news websites. The data gathered only from Indonesian news websites because we intend to portray the language functions in the national advertisements, since the state mandated curriculum in the country requires teaching materials about short functional texts that students can find in their daily life and one of them is advertisement. The curriculum requires the language function and the language features of advertisements to be taught in senior high school (Kemendikbud, 2016). This study attempts to contribute more in helping English language teachers in secondary schools to develop the teaching material for short 


\section{LITERATURE REVIEW}

\section{Speech Act Theory}

The first act of speech put forward by Austin (1965) in his book entitled "How to Do Thing with Words". Later, Searle (1969) develops this theory by publishing a book "Speech Acts: An Essay in the Philosophy of Language". He argues that communication is not just a symbol, word or phrase, but it would be more accurate to call the product from symbols, words or sentences in the form of speech acts. In speech act theory, language is seen as a form of acting. Speech is described as a form of action and words as instrument with which actions can be performed (Searle, 1969).

Searle (1969) defines speech act as an act that someone performs when making utterance or producing expressions. Both Austin and Searle suggest there are three types of actions that an addresser can manifest in speech. "They are locutionary act, illocutionary act and act said perlocution (perlocutionary act). A locutionary act is the act of making a meaningful utterance. It is also known as a locution or an utterance act" (Searle, 1969). The term locutionary act was introduces by Austin. Searle had replaced Austin's (1965) concept of the locutionary act with what he calls the propositional act. "The term illocutionary act refers to the use of a sentence to express an attitude with a certain function or "force," called an illocutionary force, which differs from locutionary acts in that they carry certain urgency and appeal to the meaning and direction of the addresser" (Austin, 1965). A perlocutionary act is an action or state of mind brought about by, or as a consequence of, saying something.

Furthermore, Searle (1976) classifies that all propositional acts fall into five main types as follows.

\section{1) Representatives}

Representatives are kinds of speech acts that state what the addresser believes to be case or not. Statements of fact, assertions, conclusion, and descriptions are all examples of the addresser representing the world. The examples are "The water is fresh. This is the most delicious bento in town" (Searle. 1976).

2) Directives

Directives are kinds of speech acts that the addresser uses to get someone else to do something. They express what the addresser wants. They are commands, orders, requests, and suggestions. They can be positive or negative. The examples are "Could you open the window, please? Don't go anywhere before I come" (Searle. 1976).

3) Commisives

Commisives are kinds of speech acts that addressers use to commit themselves to some future action. They express what the addresser intends. They are promises, threats, refusals, or pledges. They can be performed by the addresser alone, or by the addresser as a member of a group. The examples are "Don't worry. I'll be there, I'm going to get it right next time" (Searle. 1976). 


\section{4) Expressives}

Expresives are kinds of speech acts that state what the addresser feels. They express psychological state and can be statements of pleasure, pain, like, dislike, joy, or sorrow. They can be caused by something the addresser does or the hearer does, but they are about the addresser experience. The examples are "I am really sorry, What a great day" (Searle. 1976).

5) Declarations

Declarations are kinds of speech acts that change the world via words. The addresser or message sender has to have a special institutional role in a specific context to perform a declaration appropriately, for example a priest says "I now pronounce you husband and wife" or a judge says "I find your guilty as charged" (Searle. 1976).

\section{a. Advertisements}

Advertisements are one of the important cultural factors that reflect our life today. It has been "a subject for many studies and the analyzing of advertising is of growing importance" (Vahid \& Esmae'li, 2012). Ahmed (2000, p. 11) believes that "whether from a quantitative, qualitative or interpretive perspective, whether a researcher follows the modern social scientific approach, critical theory perspective or postmodernist approach, analysis of advertising and other media content is of growing importance".

Cook (1992) defines advertising as "a prominent discourse type in virtually all contemporary societies". Meanwhile, Williamson (1978: 12) states "advertisements are message systems designed to organize perceptions and create structures of meaning". As a form of marketing communication, advertising is employed to encourage, persuade, manipulate, or influence an audience (viewers, readers or listeners) to take some action (Jafari \& Mahadi, 2014). Thus, we can say that the function of advertising is to influence the reader to consume the advertised goods or services.

Nevertheless, the function of advertisement itself can also be understood from two different perspective, namely from the advertising function from the point of view of the addresser (advertiser) and the addressee (prospective consumer). The function, which the addresser intends the discourse to have, may not be the same as the function it actually does have for the receiver (Cook, 1992).

Moreover, Cook (1992) claims that in analysing advertisement as a discourse, it is not concerned with language alone. It also examines the context of communication. Cook proposes the context of communication in analysing advertisements includes substance, music and picture, paralanguage, expressions, situation, cotext, intertext, participants, attitudes and functions. In visual advertisements, the context that we often find is in the form of pictures. In this study, we will discuss the advertisements by utilizing the context in the form of pictures, co-text and function. Cook proposes, "when pictures combine with language to alter or add to its meaning, then discourse 
analysis must consider these modes of communication too". He views the co-text as a "text which precedes or follows that under analysis, and which participants judge to belong to the same discourse", and the function as "what the text is intended to do by the addressers and addressers, or perceived to do by the receivers and addressees". Hence, we can conclude that Cook's perspective on discourse analysis on advertisements is in line with Searle's point of view on locution and illocutionary acts.

\section{b. Indonesian online news websites}

The development of communications and information technology in the last decade has led to enormous changes in the communications industry that greatly enable the occurrence of media convergence by combining conventional mass media with communication technology. This can be seen in the large print media that exist in Indonesia are now beginning to utilize communication technology by creating an online news websites.

In Indonesia, the development of online media can be seen from the emergence of online news websites, such as thejakartapost.com, republika.co.id/kanal/en, en.tempo.co and en.antaranews.com. Some newspapers in Indonesia also strengthen their printed news with online version. Therefore, if online media are managed very well and professionally, it can be compete and even displace the print media (Puspaningrum, 2010).

\section{METHOD}

\section{Data Collection}

There is online news that includes advertisements in their website. After seeing some online news websites, we decided to use "thejakartapost.com, republika.co.id/kanal/en, en.tempo.co and en.antaranews.com" as the resources of the advertisements. The advertisements on those websites are considered as suitable for this study because we aim to recommend the result for the English language teachers in senior high schools who have to teach the materials about advertisements within Indonesian context, which is mandated in the national curriculum. Furthermore, the senior high schools students in Indonesia have to study about news item texts which sometimes requires them to get exposed to news websites. Our research and data collection was started in November 2017.

\section{Data Analysis}

Referring to Searle (1969), communication is not merely about symbols, words or sentences. It is more about the result of speech act performed by individuals. The 
meaning of sentences or phrases in advertisements can probably mean more than what it is written. In principle, every advertisement has its purpose to influence its reader using speech act. This research analyses speech act in the collected data to find its meaning and to categorize it according to Searle's theory on speech acts. First, we downloaded twenty advertisements from the source websites. Second, we analyzed the texts to find the speech acts and we made use the pictures in the advertisements to clarify the contexts of situation according to Cook's (1992) theory on advertisement as discourse. Third, we coded and categorized the speech acts. Finally, we counted the speech act occurrence to find out the frequently used speech acts to make our conclusion and recommendation.

\section{FINDINGS AND DISCUSSION}

Having analysed the data, we found 24 representative acts and 20 directives act in 20 advertisements. It means that representative acts used are 55\% and directive acts are $45 \%$ of the data. All advertisements have representative acts but only 15 of 20 (75\%) of the advertisements that have directive acts. The forms of the context of the advertisements in this research are pictures and brand logos. We found that two advertisements (ad 8 and ad 17) use switch coding between English and Indonesian. We decided to keep them for our data in order to show the authentic features of advertisements within Indonesian context.

\section{a. Representative Acts}

The following table presents the texts found in the advertisements that propose the illocutionary acts of representatives, accompanied by contexts that are derived from the pictures in the advertisements.

Table 1. Advertisements proposing representative acts

\begin{tabular}{ccc}
\hline Ads & Text & Context \\
\hline 1 & Asses to Progress & English Course \\
2 & Start your first Virtual Machine for free. & Virtual Machine \\
& Try it Free. & \\
3 & Satellite TV with the best HD Quality & Satellite TV \\
4 & Best of the Best & Banking \\
& Get Extra 20\% off & \\
5 & Great content, Uninterupted & Online News \\
6 & What's new, what's next, and what's interesting & Online News \\
7 & Write this way. The right way. & Writing Courses
\end{tabular}




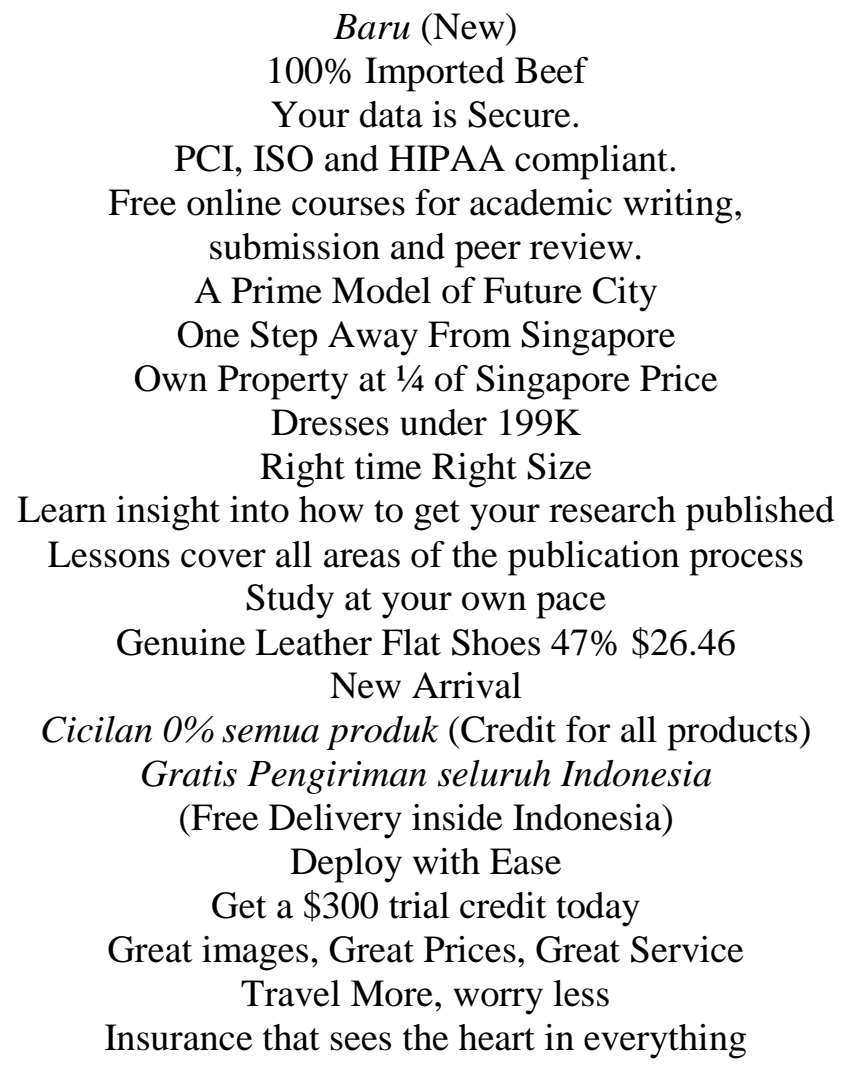

Restaurant new offering

Cloud Storage

Academic writing

course

Housing

Fashion

Snack

Writing Courses

Fashion

Fashion

Cloud Platform

Photography Service

Travel Insurance

The representative acts are mostly found in short phrases. Short phrase is chosen because addressees spend only a little time ( 2 seconds) in reading an advertisement (Plessis, 2005). Almost all the advertisements in this study use representative acts for describing their products and services to the addresses. For example, ad 11, "A Prime Model of Future City", merely asserts a model of housing that conforms to future city.

Some advertisements have representative acts for convincing addresses' need for the products, for example ad 12, "Dresses under 199K". This advertisement motivates addressees to buy, because of the cheap price of the dress. Another example is ad 13 "Right time Right Size". This advertisement only proposes a representative act, to assure the addresses the quality and the usefulness of the product (snack). This type of advertisement can motivate addressees to buy in implicit manner.

\section{b. Directive Acts}

The table below is our findings about the directives acts proposed in the advertisements. From 20 ads, only 15 of them proposed directive acts. 
Table 2. Advertisements proposing directive acts

\begin{tabular}{|c|c|c|}
\hline Ads & Text & Context \\
\hline 1 & Build a competitive advantage & English Course \\
\hline & With an English proficient workforce & \\
\hline 2 & $\begin{array}{c}\text { Start your first Virtual Machine for free. } \\
\text { Try it Free. }\end{array}$ & Virtual Machine \\
\hline 3 & Subscribe Now . Click Here & Satellite TV \\
\hline 4 & Shop Now & Banking \\
\hline 5 & Subscribe Today & Online News \\
\hline 6 & Show Events & Online News \\
\hline 7 & Join Us & Writing Courses \\
\hline 9 & Try it free. & Cloud Storage \\
\hline 10 & Register today \& start learning & $\begin{array}{l}\text { Academic } \\
\text { writing course }\end{array}$ \\
\hline 11 & Click Here & Housing \\
\hline 14 & $\begin{array}{l}\text { Be a PyeongChang } 2018 \text { Cheering member and } \\
\text { Win a free trip to Korea. }\end{array}$ & Cheering Group \\
\hline 17 & Beli Sekarang (Buy now) & Fashion online shop \\
\hline 18 & Build, Test & Cloud platform \\
\hline 19 & Try us Now & Stock Photography \\
\hline 20 & Find out more now! & Travel insurance \\
\hline
\end{tabular}

Directive acts are employed after one or more representative acts. For example, the representatives act in ad 19 "Great images, Great Prices, Great Service" is followed by "Try us Now" which is a directives act. We found that by clicking the hyperlink button in the advertisement, the addressee will be directly transported to the websites of the service. From that context of situation, we inferred that the advertisement was proposing a directive act, and the addressees are expected to access the website of the service in the advertisement as the perlocutionary act.

A directive act pushes addressee to do something like buying a product or joining a trip. In ad 10 a representative act gives information about writing and paper submission, it is followed by a directive act "Register today \& start learning". This directive encourages the addressee to join the course. A picture of a young girl strengthens the context in ad 10. It gives an impression that the target addresses are young students or novice researchers.

The directive acts used in our data are always brief, for example "Try it" or "Join Now". These brief phrases can push the reader to agree doing the proposed act without making any consideration. In this study, 5 of 20 advertisements do not employ directive act. They are merely utilized for giving information to addressees. 


\section{CONCLUSION}

From the result of our analysis, we found only two types of speech acts, which are representatives and directives. From the data we collected, we conclude that the most frequent used speech act in written advertisements within Indonesian online news websites is representative act. It covers almost all of the advertisements employed in this study. We can also infer that the advertisement strategy in Indonesia utilizes representative act which intends to highlight the good quality of the products or services, whereas, the use of directive act is situational since it is usually preceded by the appearance of representative act.

For English language learning in senior high school, we recommend that teachers provide exposures toward the linguistic features, which support them to be able to produce advertisement texts containing representative and directive acts, since both of those speech acts frequently appear in the advertisements within Indonesian online news context.

\section{REFERENCES}

Ahmed, N. (2000). Cross cultural content analysis of advertising from the United States and India. Dissertation for the degree of doctor of philosophy in University of Southern Mississippi. Retrieved from http://www.dissertation.com/library/1120842a.htm

Austin, J.1. (1965). How to do thing with words. London, Great Britain: Oxford University Press.

Chyi, H.I. \& Chada, M. (2011). News on new devices : Examining multiplatform news consumption in the digital age. ( Paper presented at International Symposium on Online Journalism). Retrieved from https://www.researchgate.net/profile/Hsiang_ Chyi/publication/265035372_News_on_New_Devices_Examining_Multiplatf orm_News_Consumption_in_the_Digital_Age/links/552847720cf29b22c9bc9 bbd.pdf

Cook, G. (1992). The Discourse of Advertising. New York: Routledge Falmer.

Ferreira, P., Rita, P., Morais, D., Rosa, P.J., Oliveira, J., Gamito, P., Santos, N., Soares, F., Sottomayor, C. (2011). Grabbing attention while reading website pages: the influence of verbal emotional cues in advertising. Journal of Eye tracking, Visual Cognition and Emotion, 1(1), 64 - 68.

Jafari, S.M. \& Mahadi, T.S.T. (2014). The language of advertisement and its features and characteristics: Investigating the issue from a deeper view. International Journal of English and Literature, 4(6), 9 - 14.

Kemendikbud. (2016). Peraturan menteri pendidikan dan kebudayaan Republik Indonesia No. 21 tentang standar isi pendidikan dasar dan menengah. Jakarta:

Kemendikbud 
Nguyen, A. \& Western, M. (2006). The complementary relationship between the Internet and traditional mass media: the case of online news and information. Information Research, 11(3), 259 - 281.

Plessis, E.D. (2005). The advertised mind: Ground-breaking insights into how our brains respond to advertising. London: Kogan Page.

Puspaningrum, B.I. (2010). Analisis perubahan media habit dalam mengkonsumsi media di era teknologi informasi: Studi kasus koran dan media online. (Postgraduate Thesis). Retrieved from http://lib.ui.ac.id/hasilcari.jsp?lokasi=lokal\&query=barina+indah+ puspaningrum

Searle, J.R. (1969). Specch Acts: An essay in the philosopyof language. New York: Cambridge University Press.

Searle, JR. (1976). A classification of illocutionary acts. Language in Society, 5(1), 1 23.

Vahid, H. \& Esmae'li, S. (2012). The Power behind Images: Advertisement Discourse in Focus. International Journal of Linguistics, 4(4), 36 - 51.

Williamson, J. (1978). Decoding advertisments: Ideology and meaning in advertising. London: Marion Boyars Publisher. 